ISSN 0258-7122

Bangladesh J. Agril. Res. 34(4) : 723-727, December 2009 Short Communication

\title{
AWARENESS OF THE FARMERS ON THE USE OF HOT WATER SEED TREATMENT DEVICE FOR CONTROLLING PHOMOPSIS BLIGHT OF EGGPLANT (Solanum melongena L.)
}

\author{
M. T. HOSSAIN ${ }^{1}$, S. HOSSAIN ${ }^{2}$ M. A. ISLAM ${ }^{3}$ \\ M. A. R. KHAN ${ }^{4}$ AND S. M. M. HOSSAIN ${ }^{5}$
}

Key Words : Hot water seed treatment, phomopsis blight of eggplant

Eggplant (Solanum melongena) is an important solanaceous vegetable crop in Bangladesh. The average yield of eggplant in the country is quite low. Among the various factors responsible for the low yield, phomopsis blight caused by Phomopsis vexans is the most devastating disease. When the leaves and twigs are infected, they become blighted and fruits get rotten and become mummified (Meah, 2003). Generally, 30-50\% loss is incurred due to the disease (Khan, 1999). To control the diseaseso, farmers use chemical pesticides like Vitavax for seed treatment and Dithane-M 45 at the vegetative and fruiting stages for controlling the disease. But, the application of chemical pesticide affects the nature and costs a lot of money. To overcome this acute problem, 1PM constitutes different components. Of various 1PM components, treatment of seeds with hot water is a useful method for controlling seed-borne diseases. Hundred percent control of $P$. vexans with $87 \%$ germination in eggplant has been achieved by the device (Hossain, 2004). But, no awareness programme has been done with Hot Water Seed Treatment Device (HWSTD) for controlling P. vexans in Bangladesh. In view of above facts, the present study was undertaken for creating awareness among the farmers in controlling Phomopsis blight of eggplant through the HWSTD.

The study was conducted at Dewannagar village under Hathazari upazila in the Chittagong district during February 2006 to February 2007 to create awareness among the farmers on the use HWSTD. According to Islam (1998), farmers were stratified as land less (no cultivable land owned but have only < 0.05 acre land), small (0.05-1.49 acres), medium (1.50-4.99 acres) and large farmers ( 5 acres and above). The data from primary sources were collected through a carefully designed questionnaire. The data were collected from the household heads of the village randomly. Total 40 respondents were taken as sample size. Statistical analysis using Chi Square $\left(\chi^{2}\right)$ Test $=\Sigma \mathrm{O}_{\mathrm{ij}} / \mathrm{E}_{\mathrm{ij}}-\mathrm{N}$ was applied for determining the difference in knowledge of farmers in identifying

\footnotetext{
${ }^{1 \& 3}$ Scientific Officer, Regional Agricultural Research Station, BARI, Hathazari, Chittagong, ${ }^{2}$ Senior Scientific Officer, T\&C Wing, BARI, Joydebpur, Gazipur 1701, ${ }^{4}$ Director, Social Science and Research Council, Planning Division, Ministry of Planning, Dhaka, ${ }^{5}$ Senior Scientific Officer, Regional Agricultural Research Station, BARI, Hathazari, Chittagong, Bangladesh.
} 
diseases between schooling and no-schooling groups. Besides, some simple statistical tools like percentage, graphs, tables, averages etc. were used to make a systematic analysis of the primary data.

Socio-economic survey made on 40 eggplant farmers revealed that more than $52.5 \%$ farmers were exclusively dependent on agriculture and 42.5 and $27.5 \%$ were small and landless farmers, respectively. In the studied area, 27.5, 32.5, 22.5 and $17.5 \%$ farmers were engaged for below 5, 5-10, 10-15 and above 15 years, respectively. Most of the farmers were found to be engaged in eggplant cultivation for 5-15 years (Table 1). Educational qualification was measured by the level of no schooling and schooling (Primary, SSC, HSC and Degree and above) in the selected village. It was found that $45.0 \%$ of the eggplant growers belonged to no schooling farmers category, $27.5 \%$ to primary, $15.0 \%$ to SSC, $7.5 \%$ to HSC and lastly $5.0 \%$ belonged to the Degree and above category (Table 1). Farmer's educational background as regard to no schooling and schooling was compared through Chi Square Test $\left(\chi^{2}\right)$. The calculated value of $\chi^{2}$ is insignificant. Thus based on the $\chi^{2}$ test, it appears that there is no relation between schooling and no schooling in identifying diseases (Table 3). Of the 40 farmers interviewed, only $20 \%$ farmers knew four diseases of eggplant viz. Phomopsis blight, Wilt, Die-back and Root rot occurring in the field and $80 \%$ farmers could not identify any of these diseases. Again, among the total farmers under study, 30 $\%$ farmers could identify Phomopsis blight disease (Table 2). It was indicated that $15 \%$ eggplant growers used Vitavax as a seed treatment chemical, $0 \%$ used hot water seed treatment, $20 \%$ farmers used other practices that was not countable under the study and 65\% eggplant growers did not use any seed treatment practices (Table 1). Maximum farmers (45.0\%) used Dithane M-45 for controlling the disease, while 37.5, 12.5 and 5.0\% farmers used Tilt, Ridomil Gold and Rovral, respectively (Table 1). When the farmers were asked about the use of chemical pesticide and 1PM for controlling Phomopsis blight of eggplant, $100 \%$ farmers voted for using 1PM technique for controlling the disease. No farmer agreed to use any chemical pesticide (Table 1). Major components of $1 \mathrm{PM}$ used in the studied area are removal of plant debrises and clean cultivation, use of alamonda and neem extracts, removal of diseased plants followed by burning and crop rotation. Observations indicated that $40.0 \%$ farmers used removal of plant debrises \& clean cultivation technique, $10.0 \%$ farmers used alamonda \& neem extracts, $22.5 \%$ farmers removed diseased plants and burnt them, $15.0 \%$ farmers used crop rotation technique and $12.5 \%$ farmers used clean seed. Thus, of the six components of 1PM, maximum farmers used removal of plant debrises and clean cultivation followed by crop rotation and removal of diseased plant and burning (Table 4). In the studied area, on demonstration of HWSTD, $100 \%$ farmers were interested to use the device for controlling Phomopsis blight of eggplant, as the technology is environmentally sound and non-phytotoxic to seed germination (Table 1). It was observed that $75 \%$ farmers 
Table 1. Salient feature of socio-economic conditions and their diseases management practices.

\begin{tabular}{|c|c|c|c|}
\hline \multirow{2}{*}{ Item } & \multirow{2}{*}{ Components } & \multicolumn{2}{|c|}{ Farmers } \\
\hline & & No. & $\%$ \\
\hline \multirow[t]{5}{*}{ Literacy Levels } & No schooling & 18 & 45.0 \\
\hline & Primary & 11 & 27.5 \\
\hline & SSC & 6 & 15.0 \\
\hline & HSC & 3 & 7.5 \\
\hline & Degree and Above & 2 & 5.0 \\
\hline \multirow[t]{4}{*}{ Occupation } & Agriculture & 21 & 52.5 \\
\hline & Agriculture +Business & 13 & 32.5 \\
\hline & Agriculture + Service & 5 & 12.5 \\
\hline & Other & 1 & 2.5 \\
\hline \multirow[t]{4}{*}{ Land ownership pattern } & Land less farmers (<0.05 acre) & 11 & 27.5 \\
\hline & Small farmers (0.05-1.49 acres) & 17 & 42.5 \\
\hline & Medium farmers (1.5-4.99 acres) & 09 & 22.5 \\
\hline & Large farmers ( 5 acres and above) & 03 & 7.5 \\
\hline \multirow{4}{*}{$\begin{array}{l}\text { Time period for eggplant } \\
\text { growers engaging in eggplant } \\
\text { cultivation }\end{array}$} & $<5$ years & 11 & 27.5 \\
\hline & 5-10 years & 13 & 32.5 \\
\hline & 10-15 years & 09 & 22.5 \\
\hline & $>15$ years & 07 & 17.5 \\
\hline \multirow{4}{*}{$\begin{array}{l}\text { Affected farmers by four } \\
\text { major diseases of eggplant }\end{array}$} & Phomopsis blight & 20 & 50 \\
\hline & Wilt & 10 & 25 \\
\hline & Root Rot & 4 & 10 \\
\hline & Die-Back & 6 & 15 \\
\hline \multirow[t]{4}{*}{ Seed treatment practice } & Vitavax & 6 & 15 \\
\hline & Hot water seed treatment & 0 & 0 \\
\hline & Others & 8 & 20 \\
\hline & None & 26 & 65 \\
\hline \multirow[t]{4}{*}{ Fungicides for foliar spray } & Tilt & 15 & 37.5 \\
\hline & Dithane M-45 & 18 & 45.0 \\
\hline & Rovral & 2 & 5.0 \\
\hline & Redomil Gold & 5 & 12.5 \\
\hline \multirow{2}{*}{$\begin{array}{l}\text { Disease control strategy when } \\
\text { they are asked to choose 1PM } \\
\text { /chemicals }\end{array}$} & Chemical pesticides & 0 & 0 \\
\hline & 1PM component (s) & 40 & 100 \\
\hline \multirow[t]{2}{*}{ Responses for uses } & Hot water seed treatment & 40 & 100 \\
\hline & Others & 0 & 0 \\
\hline \multirow[t]{2}{*}{ Mode of use } & Cooperative basis & 30 & 75 \\
\hline & Individual basis & 10 & 25 \\
\hline
\end{tabular}


Table 2. Diseases identified by the farmers.

\begin{tabular}{|c|c|c|c|c|}
\hline \multirow[b]{2}{*}{ Name of the disease } & \multirow{2}{*}{$\begin{array}{c}\text { No. of } \\
\text { farmers } \\
\text { capable of } \\
\text { identifying } \\
\text { the disease }\end{array}$} & \multirow[b]{2}{*}{$\begin{array}{l}\text { No. of farmers not } \\
\text { capable of } \\
\text { identifying the } \\
\text { disease }\end{array}$} & \multicolumn{2}{|c|}{ Average farmer } \\
\hline & & & $\begin{array}{c}\text { Capable of } \\
\text { identifying } \\
\text { the } \\
\text { disease }\end{array}$ & $\begin{array}{c}\text { Not capable of } \\
\text { identifying the } \\
\text { disease }\end{array}$ \\
\hline Phomopsis blight & $12(30.0)$ & $28(70.0)$ & & \\
\hline Wilt & $5(12.5)$ & 35 (87.5) & $8(20.0)$ & $32(80.0)$ \\
\hline Root rot & 7 (17.5) & 33 (82.5) & & \\
\hline Die-back & $8(20.0)$ & $32(80.0)$ & & \\
\hline
\end{tabular}

Note: Figures in the parentheses indicate percentages data.

Table 3. Comparison of educational status and disease identifying knowledge of farmers as determined by Chi Square $\left(\chi^{2}\right)$ Test.

\begin{tabular}{l|l|l|l|c|c}
\hline \multirow{2}{*}{ Educational status } & \multicolumn{2}{|c|}{$\begin{array}{c}\text { Diseases known by the } \\
\text { farmers (no.) }\end{array}$} & \multicolumn{2}{c|}{$\begin{array}{c}\text { Diseases not known by the } \\
\text { farmers (no.) }\end{array}$} & \multirow{2}{*}{\begin{tabular}{c} 
Total \\
\cline { 2 - 5 }
\end{tabular}} \\
\cline { 2 - 5 } & $\begin{array}{c}\text { Observed } \\
\text { values }\end{array}$ & $\begin{array}{c}\text { Expected } \\
\text { values }\end{array}$ & $\begin{array}{c}\text { Observed } \\
\text { values }\end{array}$ & $\begin{array}{c}\text { Expected } \\
\text { values }\end{array}$ & \\
\hline No schooling & 2 & 3.6 & 16 & 14.4 & 18 \\
Schooling & 6 & 4.4 & 16 & 17.6 & 22 \\
Total & 8 & 8.0 & 32 & 32.0 & 40 \\
Chi square Value & 1.62 (calculated) and 6.63 (tabulated) & & \\
\hline
\end{tabular}

Table 4. 1PM components used for controlling diseases.

\begin{tabular}{l|l|c|c}
\hline \multirow{2}{*}{ Sl.No. } & \multicolumn{1}{c|}{ Components } & \multicolumn{2}{c}{ Response of farmers } \\
\cline { 3 - 4 } & & No. & \multicolumn{1}{c}{$\%$} \\
\hline 1 & Removal of plant debris and clean cultivation & 16 & 40.0 \\
2 & Application of alamonda and neem extracts & 4 & 10.0 \\
3 & Removal of diseased plant followed by burning & 9 & 22.5 \\
4 & Crop rotation & 6 & 15.0 \\
5 & Use of clean seed & 5 & 12.5 \\
6 & Hot water seed treatment & 0 & 0.0 \\
\hline
\end{tabular}


Table 5. Justification for use of HWSTD and facilities needed for popularizing the device among the farmers.

\begin{tabular}{l|l|l|l|l}
\hline \multirow{2}{*}{ Reasons } & \multirow{2}{*}{ Item } & \multicolumn{2}{|c|}{ Response of farmers } & \multirow{2}{*}{ Ranking } \\
\cline { 3 - 5 } & & No. & $\%$ & \\
\hline \multirow{4}{*}{ Types of facilities } & Disease control & 20 & 50 & 1 \\
& Environmentally sound & 8 & 20 & 3 \\
& No hampering germination & 12 & 30 & 2 \\
\hline \multirow{3}{*}{ Training } & 16 & 40 & 1 \\
& Availability in the market & 4 & 10 & 4 \\
& Govt. loan & 6 & 15 & 3 \\
& Lower price of the device & 14 & 35 & 2 \\
\hline
\end{tabular}

wanted to use HWSTD on a cooperative basis and 25\% farmers opined to use it on an individual basis. Again, it was found that $50 \%$ farmers wanted to accept the hot water seed treatment device for successful control of diseases, 30\% farmers agreed to take it for not hampering the germination and rest of $20 \%$ farmers opined to use the device as it is environmentally sound. The response of farmers was the highest on the point of disease control. It was ranking one (Table 5). To popularize the HWSTD, it was observed that training, market facilities, govt. loan and lower price of the device were wanted by 40, 10, 15 and 35\% farmers, respectively, for using the HWSTD. Training on how to use the HWSTD got the highest ranking (Table 5). Based on the findings obtained in the present study, $100 \%$ farmers became interested to use the device for controlling Phomopsis blight of eggplant. It may be concluded that newly developed, cheap, easy, reliable and eco-friendly HWSTD may be useful for controlling the devastating seed-borne Phomopsis blight disease of eggplant. Therefore, efforts should be made to popularize and disseminate this useful technology among the farmers in the rural areas of Bangladesh.

\section{References}

Hossain, M. T. 2004. Efficiency of hot water seed treatment device for controlling Phomopsis fruit rot of eggplant. An MS thesis submitted to the Department of Plant Pathology, Bangladesh Agricultural University, Mymensingh, pp.30-34.

Islam, M. 1998. Analysis of basic need dimension of poverty. Vol. III, Bangladesh Bureau of Statistics, 1998, pp. 5-6.

Khan, N. U. 1999. Studies on epidemiology, seed-borne nature and management of Phomopsis fruit rot of brinjal. An MS thesis submitted to the Department of Plant Pathology, Bangladesh Agricultural University, Mymensingh. p. 45.

Meah, M.B. 2003. Development of an integrated approach for management of Phomopsis Blight/Fruit rots of eggplant in Bangladesh. Annual Research Report, Dept. of Plant Pathology, Bangladesh Agricultural University, Mymensingh. pp. 45-46. 